\title{
FREEDOM MOVEMENT AND THE FOURTH ESTATE- GANDHIAN PERSPECTIVES
}

\author{
MRS.V.RAMYA, ASSISTANT PROFESSOR AND HEAD, \\ DEPARTMENT OF HISTORY, SFR COLLEGE FOR WOMEN \\ SIVAKASI
}

\begin{abstract}
Mohandas Karamchand Gandhi has today become an iconic figure, a symbol of many things for many people. He is seen variously as the great opponent of European Colonism, as a champion of civil rights for racial, religious and other minorities, as an important critic of the industrial system of production, as a great pacifist, or as a person who stood for the need to resist injustice in a non-violent way. In the process, he developed the new technique of civil resistance now universally known as Satyagraha. His political, social and spiritual development during those years led to his manifesto of 1909-Hind Swaraj or 'Indian Self-rule' - a work that was considered so scandalous by the British. Gandhi returned to India in 1915 and after a period of settling in soon established himself as a champion of the peasantry, leading to confrontations with white indigo planters in Champaran in 1917 and the colonial tax bureaucracy in Kheda in 1918. He also led a successful strike in Ahmedabad. In 1917 he staged his first all India protest-the Rowlatt Satyagraha and followed this in 1920 by gaining control over the Indian National Congress and launching the Non-Cooperation Movement in which Indians withdrew their support for British Colonial institutions. This was followed in later years by two more powerful confrontations with the British-the Civil Disobedience Movement of 1930-1934 and the Quit India Movement of 1942. These movements were reflected through the Press which is the powerful media which forms the predominant role in molding the information of the public opinion. It reflects the political and socio-economic opinion of the people and emerges as an important source of information for framing the political scenario of a nation or a region according to the nature of its publication.
\end{abstract}

KEY WORDS: Press; Freedom Movement; Hind Swaraj

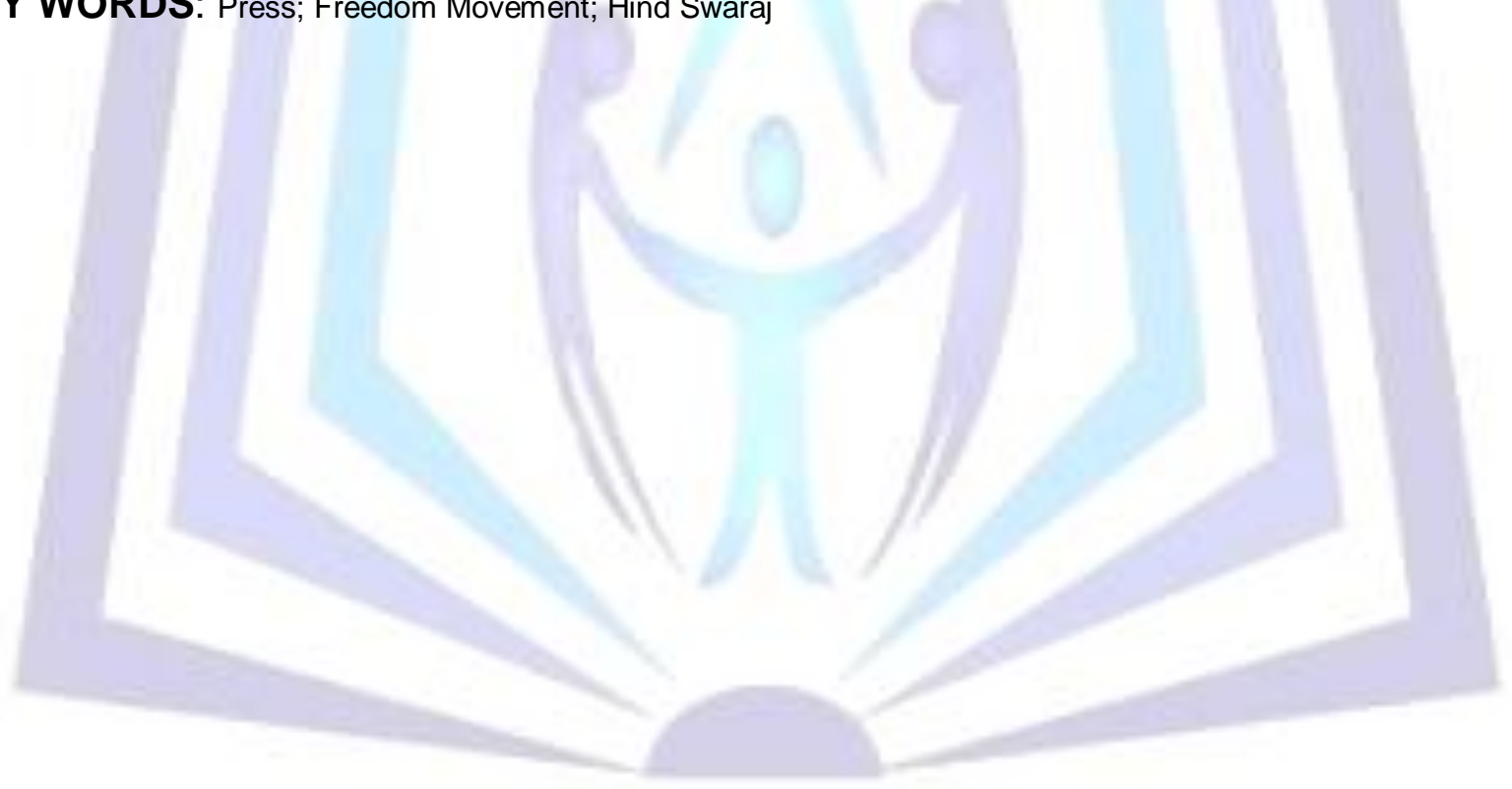

\section{Council for Innovative Research}

Peer Review Research Publishing System

\section{Journal: Journal of Social Sciences Research}

Vol .6, No.3

jssreditor.cir@gmail.com

www.jssronline.com 
The press so called as the Fourth Estate is the powerful media which forms the predominant role in moulding the information of the public opinion. It reflects the political and socio-economic opinion of the people and emerges as an important source of information for framing the political scenario of a nation or a region according to the nature of its publication. The development of the press in India can be traced out in the later half of the $19^{\text {th }}$ century when a large number of newspapers and journals began to come out. In India, the National movement paved the way for the growth of press in a new dimension. Mahatma Gandhi is an inspiration to millions of people even today. It is because he embodied the kind of transformational change that can be made when ordinary people come together to do extraordinary things. Gandhi used many tools to bring about positive changes in the people. The Fourth Estate was one of most effective instruments for achieving his purpose. Gandhi was both a visionary and a revolutionary. He was the undisputed leader of one of the greatest struggle for justice in history. He was a great communicator also. The methods of his communication he employed were novel and noteworthy. "He wrote his letters in his own handwriting. He used his publications fruitfully at a time when $83 \%$ of his countrymen were illiterate. Gandhi's publications were not circulated as large scale newspapers. But many newspapers in the world got main stories from Gandhi's publications. The picture of that small, aged man in two linen clothes was seen in newspapers and news reels everyday". The main ideas and principles of Mahatma Gandhi were put forward through his journals. He knew that the success of Satyagraha was largely dependent on its wide publicity. As a Satyagrahi, Gandhi always keenly observed the press material even in its smallest details. He took precautions against the malicious agitations engineered by his opponents. He wrote in his autobiography - "all sorts of falsehoods appeared in the press about my co-workers and myself. But my extreme cautiousness and my insistence on truth, even to the minutest detail, turned the edge of their sword."

Indian press played an important role in the growth and spread of Nationalism. A large number of newspaperswere published in different regional languages. Most of these paperswere anti-British. The Social Reformer, the Times of India, theMadras Mail, the Statesman, the Hindu, the Amrit Bazaar Patrika,the Kesari, the Maratha, the Tribune, the Bombay Samachar andRast Goftar were quite popular. They echoed the public opinion and developed a national outlook among the masses. The writings ofBankim Chandra Chatterjee, Rabindranath Tagore, Subramania Bharathi and other patriotic writers brought national awakening among the Indians. The Vernacular Press Act of 1878 curbed the freedom of the press. The Arms Act of 1878 forbade the possession of arms by Indians. It was in these circumstances that the Indian National Congress was formed in 1885 to fight for the rights of the Indians. The Indian National Congress 1885 : The dis-illusioned people of India formed an organization called the Indian National Congress. It was founded in 1885. Allan Octavian Hume, a retired British civil servant, was mainly instrumental in the formation of the Congress. The first session of the Congress was held at Mumbai. W.C. Bannerjee chaired the first session. Delegates from all parts of the country including Dadabai Naoroji, Surendranath Banerjee, Madan Mohan Malavya, M.G. Ranade, Gopala Krishna Gokhale, Pheroze Shah Metha, G. Subramaniya lyer and other liberal leaders attended the meeting.

\section{PROPAGATION OF GANDHIAN PRINCIPLES AND IDEOLOGIES THROUGH THE FOURTH ESTATE}

Gandhi considered the media persons as the torch bearers of national progress. Mahatma Gandhi transcended the bounds of race, country or religion and became the prophetic voice of the twentieth century. The depth of his insight, the sweep of his vision, the purity of his character, the steadfastness of his devotion to ideals, his titanic heroism and utter trust in the higher attributes of the spirit were unique. As Pandit Jawaharlal Nehru rightly remarked, "The light that has illuminated this country for these many years will illuminate this country for many more years; and a thousand years later, that light will be seen in this country, and the world will see it and it will give solace to innumerable hearts."Gandhi followed the twin stars of Truth and Non- Violence all along the path of his most difficult and eventful life. He acted according to principles, not expediency. Gandhi worked ceaselessly for the realization of what the sociologists call 'Common Human' values, for the triumph of the common human way of life. He did not believe imposing his values or way of life upon others; by the same token, he resisted unto death the attempts of others to impose upon his or his people their values and way of life. Gandhi, the Saint of Sabarmati was one of the greatest spiritual forces of all times. His dharmic approach and such a way of living brings man near unto God. Modern methods of transportation and communication have spanned the oceans, linked countries together, and made it easy for man to travel from one part of the world to another. Gandhi visualized such a world far ahead. He put forward a way of life commensurate with this change. This was another uniqueness found in this great man. Gandhi admired everything in Indian cultural heritage. He believed that everything what a man need is in this ancient land.

The first twenty years that Gandhi spent in South Africa, had a decisive influence on his later life. His political ideologies, his greatest contribution to Indian politics, took shape in South Africa. The concept of non co-operation, found in the works of Ruskin, Tolstoy and Thoreau influenced him significantly. These three illustrious writers advocated non co-operation as an effective tool in the hands of the civilians against a tyrannical and oppressive government. It was Gandhi, however, who gave action to these valuable words through his satyagraha agitations first in South Africa and later in India, in its struggle for freedom. At this juncture, it is important to understand the meaning of satyagraha, as projected by Gandhi. Passive resistance, adherence to truth, civil disobedience, non-cooperation and pacifism, perhaps capture the essence of satyagraha as enunciated by Gandhi.

Another critical concept that finds expression in Gandhian philosophy is that of ahimsa. Gandhi had adopted this central philosophical tenet from Jainism and Vaishnavism that exercised a strong influence in Gujarat. For Gandhi, ahimsa was not a mere moral value but a political weapon par se, embodying virtues like chastity, self control, the strength to lead a simple life and the notion of swaraj. For Gandhi, swaraj entailed an internal self rule along with freedom from the rule of 
the colonial government. Using these invincible ideological tools, Gandhi launched a massive satyagraha movement in South Africa against the hegemony of the British colonial rule and succeeded in uniting all major sections of the Indian community in South Africa, irrespective of their religious affiliations. Christians, Parsis, Muslims, Hindus, South Indians, upper class merchants and the poor laborers coalesced under the inspiring ideals of the Mahatma. Hinduism and Christianity also had considerable influence on the formation of his ideologies.

Gandhi said, "My life is my message."His life was an experiment with truth. Before this experiment he believed that 'God is Truth". After the experiment he realized that "Truth is God". Gandhi's life of 89 years, his writings of about 110 volumes and above one lakh printed pages is the story of this great experiment. In his writings of Hind Swaraj Gandhi revealed his vision as conversation between the reader and editor. His journalistic skill is extra ordinary. In 1903, in South Africa, Gandhi started a weekly newspaper, Indian Opinion, issued every Saturday in four languages. Three years later Gandhi had to confine it to two languages for want of competent editors. He himself edited the paper in these two languages and issued the paper punctually until he left South Africa in 1914.

From India Gandhi continued supporting 'Indian Opinion' all his life by providing regular editorial material and moral and financial support. In 1919 Gandhi started two weeklies in India, Young India and Navajivan and issued them regularly all his life except for short intervals durations his press was under government siege. In 1933 Gandhi added a third weekly. 'Harijan' (which means the 'Children of God') and ran it all his life except when the press was ceased.

More than $75 \%$ of the content in Gandhij's papers came from his own pen. It is estimated that during his life time Gandhi wrote more than 10 million words. That translates into 500 words every day for 50 years. What a unique writer he was! And almost all of his writings were related to personal improvement and social and political reform. In short, we can easily say that the single factor that helped Gandhi the most in earning the title of 'Mahatma' and the leadership of the masses was his dedication of running the weekly newspapers for nearly 40 years of his life.

\section{GANDHI-CRUSADER OF THE FOURTH ESTATE}

Gandhi used newspapers to educate himself and his followers. Newspapers served him as a powerful ally in his struggle for the removal of racial discrimination. They are a powerful weapon for him to social change and political struggle. Political and social reforms led by Gandhi got ample coverage both in his publications and in other newspapers

\section{INDIAN OPINION}

Gandhi published his articles in English and in Gujarati in his Indian Opinion. In South Africa, he was a lawyer, a political activist, and above all, a journalist. Gandhi was quite well informed of what was going on in the Indian subcontinent. In the first chapter of Hind Swaraj, Gandhi stated the three objectives of the newspaper, the first of which is to understand the popular feeling and to give expression to it; the second is to arouse among the people certain desirable sentiments; and the third is to expose popular misconceptions fearlessly. To a certain extent, the people will have to be expressed; certain sentiments will need to be fostered and defects will have to be brought to light. The three functions mentioned here are also the functions that he had proposed for his newspaper, 'Indian Opinion. Although this journal supplied a real want, what may be termed a commercial demand had to be created. In other words, the paper had not only to find its matter, but its readers also" Gandhi added, "It (Indian Opinion) was to educate public opinion to remove causes for misunderstanding; to put before the Indians their own blemishes and to show them the path of duty while they insisted on securing their rights. We (the workers of Indian opinion) write impersonally and no one on the staff of this journal claims any glory over the matter. We therefore think it but right to take the public into our confidence. The journal Indian Opinion is a great instrument of education. It is necessary for every Indian to look upon the journal as belonging to him, not as something mine". The objects of the journal are threefold: first, to make our grievances known to the Government, to the whites here in South Africa and in England and to people in India; Secondly to tell our people of their own shortcomings and to exhort them to overcome these and, thirdly - and this is perhaps the principal objective to eliminate the rivalry between Hindus and Mohamedians and the caste distinctions among Gujaratis, Tamilians and Bengalis as well as those practiced elsewhere in India. All persons connected with the journal are such that they can earn their livelihood by other means. 500 complimentary copies of the journal were published first. In the beginning, The Indian opinion had its editions in Gujarati, Hindi, Tamil and English.Satyagraha would probably have been impossible without Indian Opinion.

Gandhi viewed his journalistic attempts as an 'ethical experiment'. He never considered it as a business even though he has frankly described the difficulties faced by newspaper management in his autobiography. But in this study, we are giving importance to the journalistic approach of Mahatma Gandhi; not the newspaper management techniques. We are trying to evaluate the contributions of Gandhi to the Journalistic field. He influenced millions of people through his writing.

Sjt. Madanjit and Magalal Gandhi helped the Mahatma in managing the 'Indian Opinion' Sjt. Madanjit was canvassing subscribers for the 'Indian Opinion'. Gandhi, never considered whether there was profit or not Mr. West left the journal when he discovered that there was no profit. But Gandhi did not blame him. The idea of having an engine to work the press had not appealed to Gandhi. "I had thought that hand-power would be more in keeping with an atmosphere where agricultural work was also to be done by hand. But when the idea was not found feasible, an oil-engine was installed for the purpose. In the initial stages they had to burn midnight oil for bringing art each issue of the journal.

The publication started in 1904 fell in loss many times. Gandhi himself worked hard and compensate the loss of the weekly. Most of the articles in it are written by Gandhiji. Great men like Tolstoy, appreciated Gandhiji. The service, which Indian opinion done to the society was great. The publication was a mirror of Gandhiji's life. Today we are hearing about 
the principles like, 'media is the message' and 'media man is the message'. But Gandhi, the media man was the message behind his publications. He never wrote a word for the sake of false praising to others. He wrote things after deep study. He never exaggerated things. Gandhi wrote in his autobiography that the journal was helped for his own self control and self purification.

\section{ORIGIN AND DEVELOPMENT OF 'INDIAN OPINION'}

The first editor of 'The Indian Opinion' was Mr. Mansukhlal. But most of the work was done by Gandhiji himself. Gandhi himself wrote the editorial. It was published in four languages-Gujarati, Hindi, Tamil and English. Hindi and Tamil editions were nominal in circulation. So Gandhi stopped the publication of those two editions. On an average 75 sovereigns was the expense of publication. Gandhi gave the money without expecting anything in return.Gandhi wrote in his autobiography: "Indeed the journal became for me training in self restraint, and for friends a medium through which to keep in touch with my thoughts. The critic found very little to which he could object. In fact the tone of Indian Opinion compelled the critic to put a curb on his own pen. Satyagraha would probably have been impossible without 'Indian Opinion'. The readers looked forward to it for a trustworthy account of the satyagraha compaign as also of the real condition of Indians in South Africa. For me it became a means for the study of human nature in all its casts and shades, as I always aimed at establishing an intimate and clean bond between the editor and the readers. I was in undated with letters containing the outpourings of my correspondent's hearts. They were friendly, critical or bitter, according to the temper of the writer. It was a fine education for me to study, digest and answer all this correspondence."

The journal was an effective means of educating and consolidating the Indian community. The Indians all over the world were kept in touch with the course of events in South Africa through this weekly. It was a useful and potent weapon in the struggle of Indians in South Africa. Gandhi expressed through it his thoughts and ideas on all subjects of interest to the Indians. 'Indian Opinion' carried some articles in Gujarati language. Through the Gujarati columns in particular, Gandhi tried to educate the Indians in South Africa in self-discipline, sanitation and good citizenship and to prepare them for satyagraha. He sought to inspire his readers by recounting the lives of great men and women. For 10 years Gandhi poured out his thought and feeling on all the subjects of interest to the Indian community.A girl named Ms. Shlesin helped Gandhi very much in publishing 'Indian Opinion', especially when he was jailed. Her's was a selfless service. She was sending the communications and doing all financial correspondence. Gandhi utilized the money getting from his cases for 'Indian Opinion'. Mr. Madangit helped Gandhi by joining subscribers and collecting subscription. Gandhi charged the office and press of 'Indian Opinion' to phoenix settlement. He gave equal living wage to all. He insisted on that the journal published in the right day every week. The phoenix have almost a self sufficient atmosphere. Each one worked hand in hand for the success of the journal. The editor Mansukhlal Nazar controlled the paper from its Durban Branch.

The publication was an important tool for the political movement led by Gandhiji and the Natal Indian Congress to fight racial discrimination and win civil right for the Indian immigrant community in South Africa. Through the $19^{\text {th }}$ century Indians were brought to South Africa as indentured labour by the authorities of the British Empire, which governed both South Africa and India. Along side various multi-ethnic communities, the Indian community suffered from significant political, economic and social discrimination, administered by the system of apartheid. In the aftermath of the Boer War, the government of General Smuts introduced significant restrictions on the civil rights of the Indian immigrant community, giving the police power to warrant-less search, seizures and arrests. All Indians were required to carry identification and registration cards at all times. Working as a lawyer in the Natal province, Gandhi organized the publication with the aim of educating European communities in South Africa about Indian needs and issues.At Phoenix, the press workers were governed by a new work ethic- they would all have a share in the land, in the profits if there were any, they would grow crops to sustain themselves and they would work jointly to produce Indian Opinion. The newspaper's editors included Hebert Kitchin, Henry Polak, Albert west, Manilal Gandhi, who was the paper's longest serving editor (for 36 years) and Sushila Gndhi. All but one of its editors spent some time in jail.

\section{PURPOSE OF INDIAN OPINION}

The Indian opinion began by adopting a very moderate tone, reiterating its faith in British law and seeking not to provoke the hostility of British officials. However, the Indian Opinion boldly highlighted the poor conditions under which indentured labourers worked. Editorials exposed the discrimination and harsh conditions prevalent in the agricultural estates where indentured Indians were employed. Cases of harsh treatment by employers were publicised and the astoundingly high rate of suicide amongst Indians was pointed out. A campaign to end the system was launched and editor Henry Polak, a friend of Gandhi's, went to India to mobilise support. From 1906 onwards it became a vehicle for challenging state laws and urging defiance of these when these were clearly unjust. This tradition began during the satyagraha campaign between 1906 and 1913 by which Gandhi resisted the attempts of the colonialists to impose passes on Indians in the Transvaal. The paper played a decisive role on defeating the registration drive of the officials. Its pages paid tribute to local resisters and Brian Gabriel, one of Natal's earliest Indian photographers, provided visual coverage.

The Indian opinion was a means of bringing news about Indians in the colonies before the public in India. The pages of Indian opinion provide a valuable historical record of the disabilities that Indians suffered under. It also provides an invaluable record of the political life of the Indian community. Gandhi's experience with the publication and the political struggle in South Africa proved a major experience for him that helped him in his work for the Indian independence movement. In India he would publish Young India, Navajivan and Gujarat Samachar. The Indian Opinion continued to publish for many decades and played a significant role in the wider civil rights struggle of South Africa. But it also suffered from not being a commercial enterprise, but rather a publication committed to serving social causes. Gandhi was clear 
about the nature and content of his newspaper. It would not carry any advertisements nor try to make money. Instead, he sought subscribers who would give donations. Indian opinion became certainly a most useful and potent weapon in the struggle for the rights of Indians in South Africa. In South Africa his writing often made the white racists look ridiculous: The white barber refused to cut my black hair, extending his colour prejudice to not only non-Christian skin but nonChristian hair as well.

The paper was important for understanding Gandhi. Through it Gandhi was able to communicate not only with his colleagues but with the general public on the crusade he was leading on political, social and economic issues. The critics found very little to which they could object. In fact, the tone of 'Indian Opinion' compelled the critics to put a curb on his palm. From Gandhi's writings overseas readers could form a time picture of the happenings in South Africa. Among the distinguished readers were Gokhale in India, Dadabhai Naoroji in England and Tolstoy in Russia. Gandhi worked hard for this weekly. He got two hundred journals per week in exchange of Indian Opinion, read each one of them carefully and reproduced such news as might benefit the readers of Indian Opinion.

Gandhi was a successful journalist but never intended to make a living from journalism. In his opinion the aim of journalism was service: "Journalism should never be prostituted for selfish ends or for the sake of carrying a livelihood. And whatever happens to the editors or the journal, it should express views of the country irrespective of consequences. They will have to strike a different line of policy if they wanted to penetrate into the hearts of the masses."When he took charge of the Indian Opinion, it was a losing concern and had a small circulation of four hundred copies. For some months Gandhi had to contribute Rs.1200 per month to keep it going. Altogether he incurred a personal loss of Rs. 26000/-. In spite of this heavy loss, he later decided to keep out advertisements in order to devote more space for propagating his ideas. He knew that he would not be able to serve truth and remain independent if he accepted advertisements. He never cared to increase the sale of his journals through improper means, nor to compete with other newspapers.

The journal did not project any sensational topics. He untiringly wrote on constructive work, Satyagraha, non-violence, diet, nature-cure, Hindu-Muslim unity, untouchables, spinning khadi, swadeshi, village industries and prohibition. He stressed the need of re-orientation of education and food habits and was a severe critic of national defects. Indian opinion more or less forced South African provincial regimes to modify their repressive laws against Indians. One-day Gandhi got a call from Bihar where the Indigo farmers of Champaran were subjected to the same kind of indignity and exploitation as the indentured labourers in South Africa. He promptly went there and investigated the issues, and produced a report that would be the envy of the greatest investigative journalist anywhere in the world.

\section{YOUNG INDIA}

'Young India' (1919-1932) was an English weekly journal published from Bombay under Gandhi's supervision. It was started from Bombay on $7^{\text {th }}$ May 1919. On $8^{\text {th }}$ October 1919 Gandhi became the editor of its Ahmedabad edition. Messrs. Umar Sobani and Shankar lala Banker were controlling 'Young India' in the first phase. Gandhi had already learned from his experience in the 'Indian Opinion' that, a journal needed a press of its own "Moreover the press laws in force in India at that time were such that, "if I wanted to express my views untrammeled, the existing printing presses, which were naturally run for business, would have hesitated to publish them. The need for setting up a press of our own, therefore, became all the more imperative, and since this could be conveniently done only at Ahmedabad, Young India too had to be taken there".

Through the journal Gandhi commenced to the best of his ability the work of educating the reading public in Satyagraha. It had wide circulation which at one time reached the neighbourhood of forty thousand. He set his face against taking advertisements in his journals from the very first. "Incidentally, these journals helped me also to some extent to remain at peace with myself for, whilst immediate support to civil disobedience was out of the question; they enabled me freely to ventilate my views and to put heart into the people. Thus I feel that both the journals rendered good service to the people in this hour of trial, and did their humble bit towards lightening the tyranny of the martial law."

The power of satyagraha was imbibed in whatever Gandhi wrote. In 1930, Gandhi declared the decision for salt satyagraha in Young India. Monday and Wednesday are the days of Gandhi's vow of silence. In these days he wrote articles for Young India and Navajivan. Gandhi revealed his thoughts through these publications even in the disobedience. The hardship of martial law was also simplified due to these publications.

Gandhi had been frequently writing on various aspects of journalism. To him editorial independence, adherence to truth and self-restraint were the three over-riding considerations for journalism. In his message for the editor of the newspaper, 'The Independence' on $30^{\text {th }}$ January 1919 he wrote: "In wishing you success in your new enterprise, I would like to say how I hope your writings would be worthy of the title you have chooses for your journal; and may I further hope that to a robust of independence you will add an equal measure of self-restraint and the strictest adherence to truth? Too often in our journals as in others do we get fiction instead of fact and declamation in place of sober reasoning. You would make 'The Independence' a power in the land and a means of education for the people by avoiding the errors I have drawn attention to." This was the same line of thinking of Gandhi's publications also.

In India Gandhi published his journals for about 30 years, without the aid of any advertisement. He suggested that for each province, there should be only one advertising medium, printing decent descriptions of things useful to the people. After accepting the editorship of Young India, he was keen on conducting a Gujarati paper because a vernacular paper was a felt want. Editing a newspaper in English was no joy to him. He brought out Navajivan, the Hindi and Gujarati version of 
Young India, and contributed many articles regularly. He was proud to say that many readers of his publications were the farmers and workers who really made India.

The price of 'Young India' was one anna per copy. He sustained no loss in running it. But when he was jailed the circulation dropped down to 3,000. Under heavy pressure of work he had to write a lot and had to work late at night or in the early hours of the morning. He often wrote on a running train. Some of his famous statements or editorials bore the mark "on the train". When his right hand got tired, he wrote with the left. Curiously enough, his left hand writing was more legible. Even while convalescing he wrote three to four articles every week.

Gandhi was first jailed in India for his bold articles printed in Young India. He never submitted to any gagging order issued by the Government. When he was not allowed to express his deepest thoughts, he stopped writing. He was confident that he could any day persuade his readers to copy his editorials for him and circulate the news. He knew his paper could be suppressed but not its message so long as he lived. By not caring for the aid of printing room and compositor's tick, the hand written paper, he assured, could be a heroic remedy for heroic times.Issue after issue of the 'Young India' bore good testimony to the Mahatma's journalistic genius which manifested in his appeals to the government to do what was 'just and righteous'. His writings were not meant to evoke hatred and contempt. Gandhi believed in healthy journalism and avoided malicious techniques of communication. He wrote, "My writing come not be poisonous. They must be free from anger, for it is my special conviction that we cannot truly attain our goal by promoting ill-will against the rulers or anyone else. My writing cannot be free from hatred towards any individual because it is my firm belief that it is love that sustains the earth.

Gandhi, fully devoted his time for propagating Khadi during the three years from 1924. 'Young India' greatly helped him in this mission.In 1926 Viceroy Lord Reading returned to England and Lord Irvin came to India. This was not published in 'Young India'. Gandhi published a letter on whether it is good to kill mad dogs which was one and a half page lengthy. This continued in following four issues. The selection of items in the magazine was remarkable. There was a regular column named 'letter to the editor'. This gives enough space to the readers to respond on various issues. They got the views of Gandhi as reply to these letters which were published in the weekly. Gandhi continued his writing even when he was ill. Major decisions of Gandhi were revealed through his weeklies.

Several times the Britishers raided the office of 'Young India'. But, Gandhi remained fearless. The authorities could not find any document which was illegal or antinational, Gandhi considered that fearlessness and freedom of expression are the base of value based journalism. 'Gandhi's Autobiography', 'Satyagraha in South Africa', 'From Yervada Mandir' and 'Anasakthiyoga' are first published in his weeklies. This also helped increase the circulation of the publications.

\section{NAVAJIVAN}

Navajivan (1919 - 1913) was a Gujarati weekly edited by Gandhiji and published from Ahmmedabad. It had occasional biweekly issues. Navajivan was first published on $7^{\text {th }}$ September, 1919. It was the time of protest against Rawlatt Act. So it was not easy to get permission for a new weekly. So Gandhi bought the 'Navajivan Anasatya' weekly of Indulal Yajnik. It had only 600 copies of circulation before Gandhiji became the editor. It is increased to 2500 copies after Gandhi's arrival. The second issue got 5000 copies and the third got 6000 copies. It was published from a small press. When circulation increased, a large press becomes a necessity. Other printing units are not ready to print the weekly from their press because of they feared the authorities. So Gandhi and Anasuya Behn collected Rs. 6000 and started a new press. This was today's 'Navajivan Mudranalaya.'

Many asked Gandhi Why he hesitated to start a daily in English language. He replied: "I want to communicate with the farmers and weavers, who lived in huts in remote villages. The message of satyagraha must reach them. For that, the language must be understandable to them.Navajivan like all other publications of Gandhi was a part of our struggle for freedom.In 1930, the government abolished the printing of Navajivan. In 1931 it was re-started. But the Government intervened again. In 1933, Gandhi put an end to both the papers. After that Navajivan Trust and Navajivan Publishing house started. The copy-right of all of the works of Mahatma is to this publishing house. "Navajivan was read in the farthest corners of India, sometimes in groups. Gandhi's articles were reproduced in almost all the newspapers in India."

The name 'Navajivan' meant the renewal of the country and the magazine. The renewal of Gujarati language and literature also was the aim of Gandhiji. It brings a new energy to the life of the people also. Politics was the most important topic in the weekly. Gandhi tried to increase the moral standard and courage of the readers continuously. He tried to purify them. To make them complete human beings was his primary aim. Gandhi knew that it is inevitable for 'Sampoorana Swaraj' which was proclaimed by him at Godhra on November 1917. In the first issue itself Gandhi wrote about this 'dharmic renewal': "I practiced some dharmic values in my life after continuous and hard effort. It is my duty to inform others, this happiness and culture." Gandhi tried to inspire all the Indians through his weekly. Gandhi never tried to write these things as a philosopher in volume of books. He gave his message in simple language for common people in the village. He took his own approach to social and political problems. Thus he conveyed to common people in a simple way. Gandhi put forward some conditions for the publication of Navajivan. He informed it through the weekly to the readers. This is based on the Gandhian journalistic values. The conditions are

(1) The weekly take any advertisement for money.

(2) It will not continue in loss

(3) Navajivan is not a business. To increase the circulation, the standard of the weekly 
does not decrease.

When Navajivan got a subscription of 9000, Gandhi wrote: "I don't want to make it 2000. If it becomes 50000, I will not show extreme happiness." There was not enough printing facility for Navajivan in that time. The numbers of persons worked in the weekly are also low in number. But in content wise the magazine was in frontline. Gandhi said to the readers that they should not evaluate the weekly by reading only one issue. He published translated articles from other languages like Bengali. Many famous persons wrote in it and Gandhi regularly communicated with them. He gave ample importance to the feedback from the readers.

Navajivan was running at a loss at one stage. Then the price of one copy was 16 paise. 8 paise had to be spent on the raw paper alone. But Gandhi was not willing to decrease the quality of the paper. He insisted on using good quality paper. $\mathrm{He}$ decreased the size and the number of pages. Number of pages was decreased to 12 from 16 . In Bombai and Ahmedabad Navajivan sold on five paise instead of four for single copy. Gandhi informed the readers that, if he increased the number of copies, the loss will also increase. So in that stage, Gandhi and the readers struggled not to increase the circulation. When Navajivan was started, eight pages were promised but, the circumstances having permitted, sixteen pages were given. Gandhi did not avoid any subject because of lack of space. He concised articles with greater effort and attempted to include all of them. Gandhi was against to write lengthy articles in newspapers and weeklies. He criticized the publication of large articles in newspapers. He observed that the writer failed to communicate his ideas to the readers in such lengthy writing. Sometimes the ideas become not easily understandable. Gandhi insisted on that the articles in the Navajivan must be short and matter-of-fact. His thrust was on social issues. The main aim of the magazine was service.

While continuing publication, Navajivan become profitable. Gandhi could increase pages up to 16 without any loss. But he was not profit motive also. Navajivan continued the publishing with the help of editor Gandhi, his co-workers and readers with a fully service mentality. At the same time he was very calculative and keenly observing the economic side of the paper. His Gujarati Beniya tradition of traders was considered as one of its causes by observers. Gandhi wrote: "These two weeklies ('Navajivan' and 'Young India') enabled me freely to ventilate my views and to put heart into the people. Thus I feel that both the journals rendered good service to the people in this hour of trial, and did their humble bit towards lightening the tyranny of the martial law." Gandhi was jailed in 1922 for writing articles against the government in his weeklies. He was accused sedition. Even then he was not go behind from his journalistic attempts. Another example for Gandhi's deep- rooted commitment is that on communal harmony. He devoted one full issue of his weekly for this. At the same time, we can see that he devoted his full life for communal harmony and unity.

\section{TABLE 1.CIRCULATION FIGURES OF BENGAL NEWSPAPER REPORTS IN 1921}

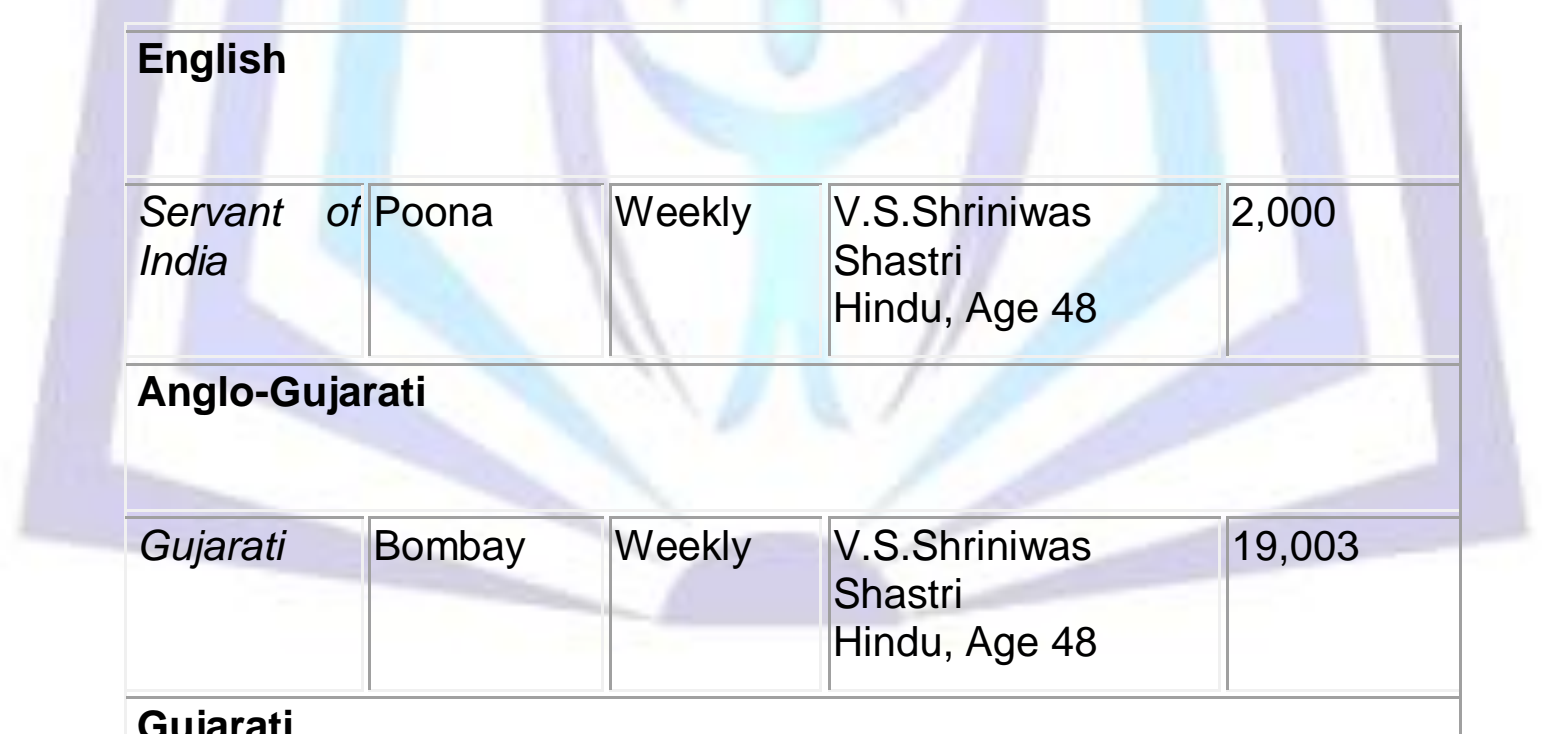

\begin{tabular}{|c|c|c|c|c|}
\hline Navajivan & Ahmedabad & Weekly & $\begin{array}{l}\text { Mohandas } \\
\text { Karamchand Ghandi } \\
\text { Hindu, Age } 53\end{array}$ & 23,000 \\
\hline
\end{tabular}




\begin{tabular}{|l|l|l|l|}
\hline Sandesh & Bombay & Daily & $\begin{array}{l}\text { Achyut Balvant } \\
\text { Kolhatkar } \\
\text { Hindu, Age 41 }\end{array}$ \\
\hline
\end{tabular}

\title{
Source: Indian Newspaper Reports-1868 to 1942
}

\begin{abstract}
HARIJAN
'Harijan' (1933-1956) is the English weekly journal founded by Mahatma Gandhi and published under the auspices of the Harijan Sevak Sangh, Poona and from 1942 by the Navajivan Trust, Ahmedebad. The weekly suspended publication in 1940 during the 'Individual satyagraha'; resumed in January 1942, but again stopped during the 'Quit India' Struggle. The main aim of starting 'Harijan' was to teach the masses about Gandhi's ideas of satyagraha, non-violence and nonviolent resistance. The burden of leading a nation towards freedom and the contingency of having to face trials followed by jail terms did not stem the flow of writing from Gandhi's pen. There was not a day when he was not writing on some issue or the other in his weeklies. Gandhiji started Harijan on $11^{\text {th }}$ February, 1933. It was a continuation of the 'Navajivan'. The very word 'Harijan' means the people of God. Gandhi called the downtrodden and marginalised people, 'Harijan'. His aim was the upliftment of the poor, helpless millions. This name had been suggested by a reader of 'Navajivan' in response to Gandhi's call through the weekly. Names such as untouchables, defused class, scheduled caste, last born... etc., were not acceptable to him. Gandhi earnestly desired that the weekly should be circulated all over India. G.D. Birla sponsored the English weekly. R.V. Shasti was its first editor. The growth of the weekly was quite fast. It soon became a selfsupporting venture. Gradually Gandhi started Harijan in various other languages. Its Hindi edition was named 'Harijanbandhu'. It got Gandhi's special attention and supervision, because it was the most widely read edition. Gandhi wrote articles for the Hairjan regularly in a simple, vivid language. He gave his own version to deep issues. Mahadev Desai, K.G. Mashruwala, Jawaharlal Nahru, R.R.Diwakar C.Rajagopalachari, Kaka Kalekar and many other freedom fighters wrote regularly in the weekly.
\end{abstract}

The main aim of the publication was to remove untouchability from the society. Attempts like temple- entry were supported whole heartedly by Gandhiji. He said, 'Untouchability is a wound in the body of Hindu religion. It must be remedied by all.' Harijan' also helped Gandhi to propagate the constructive programme. Harijan weekly was a news source to many of the major newspapers and news agencies at that time. Every week Gandhi, had to say something important to his readers. Most of the newspapers both in India and on abroad make it front page news item. Harijan was published on all Fridays with news, small write ups, informative pieces, local information, translated articles etc. The annual subscription rate of the weekly was Rs.4/- This also helped to attain good circulation.

During the time of Communal Award amendment of law Gandhi stopped the publication. This was as a protest to the Government. This was in 1940. After six years Harijan was re-started its publication and continued up to 1949. Gandhi's publications are the part of history today. But it was very helpful to the study of history of India's freedom struggle. When Gandhi started 'Harijan', he asked Dr. B.R. Ambedkar for a message. Dr. Ambedkar not responded positively. He replied that the caste Hindus not accept his message. Gandhi included this write up of Ambedkar in the first issue of English Harijan.

There are no such journals which are influential like 'Harijan' in the world among small publications. Gandhi wrote: "Harijan service is a duty the caste Hindus owe to themselves." It is a fact that untochability in India was decreased very much as a result of these type of message. He could win the people of India by advocating the principles of truth and non-violence which are the guiding principles in all his activities.Once Gandhiji wrote a letter to Sir Edward Benthall, Managing Director of the Titaghur Paper mills, asking him to give paper free of cost for the Hindi edition of the Harijan. Sir Benthal was not ready to make a gift of the paper but promised to give advertisements in the paper so that Gandhiji could buy enough paper for the newspaper. Gandhiji said that the 'Harijan' would mention that the paper was a gift from Titaghur paper mills and that itself would be a good advertisement. Benthall was not agreeable to such a mere acknowledgement. He insisted on a direct advertisement. But the 'Harijan' had decided not to take advertisements for pecuniary benefits. This policy of keeping away from advertisements was unwavering and was zealously adhered to.

Gandhiji had set ideas on the functions to be performed by the press. In his autobiography. Gandhiji had defined the objectives of journalism as follows: "One of the objects of a newspaper is to understand the popular feelings and give expression to them; another is to arouse among the people certain desirable sentiments; and the third is fearlessly to espouse popular defects". Gandhiji exerted a powerful influence on the promoters of newspapers and frequently induced them to be fearless. He earnestly wanted frank opinions on his personal views to be expressed. "His appeal to the editors of newspapers was that they should not surrender their conscience at any cost." Knowing full well, the power of the pen, Gandhiji exploited the situation by starting Harijan for the service of the nation. Gandhi's faith in the Indian masses was unshakeable and people's confidence in him had remained profound and abiding.

The most remarkable service Gandhi rendered to India or rather to Hinduism, as a religious reformer, was his stern opposition to the rigid caste system and unsociability. Before him, though many religious reformers had attacked it, none 
of them had so successfully revolutionized the attitude of India's intelligentsia towards untouchability as Gandhi. For this aim 'Harijan' halped Gandhi very much. He wrote in 'Harijan': "Harijan service will be always after my heart and will be the breath of life for me, more precious than the daily bread, but I cannot live without Harijan service for one single minute."Gandhi's work influenced the legal system of the country. This is in fact, the power of the pen also. In 1933 the state of Baroda passed a law named 'the Caste Tyranny Removal System. Travancore followed this example, opening all the temples for Harijans. Now, untouchability is forbidden by Article 17 of the Indian constitution. Gandhi realized far before that $1 / 6^{\text {th }}$ of Indian population was Harijan. He visualized the upliftment of India in their upliftment.

In that time, the voice of Mahatma Gandhi was the voice of India. Harijan was not a news paper in the usual sense of the term. It was more a views paper, conveying to an eager world what the Mahatma though on a wide range of subjects. He answered the questions of his readers about various subjects through the weekly. Once there was an occasion which 'Harijan' refused to publish Gandhi's own article. Gandhi revealed the truth that Manu is sleeping near him at night, in a write up. Two editors resigned after getting this write up for not to publish it. The trustees of Harijan also hesitate to publish this. Gandhi became disappointed. After Gandhi's death, his disciples attempted to keep the Harijan going. Commendable as the effort was, it had its great short coming, for Harijan without Gandhiji was like a body without the soul. Men like Mashruwala most faithful Gandhians, tried hard to keep the journal going but they must have known from the very beginning that they had set for themselves an impossible task. It became more and more apparent as the weeks rolled by until ennui possessed the editors and the journal had its natural 'death'.

\section{EMERGENCE OF GANDHI: AS A LEADER OF INDIAN NATIONAL MOVEMENT}

In the year 1915, Gandhi returned to India. During his initial days, he spent his time at the Sabarmati Ashram in Ahmedabad, quite unknown to the masses. In this context it is pertinent to mention that Gandhi sought guidance from Gopal Krishna Gokhle in assuming his political stance. It was Gokhle's advice to Gandhi that he should first study in details the socio-political scenario prevalent in the country and then act accordingly. However, Gandhi soon emerged on to the political scenario through his able leadership.

Gandhi gave voice to the cause of the oppressed cultivators in Champaran district of Bihar who were suffering under tyranny of the European indigo-planters. Threatened by the outbreak of large scale satyagraha struggle, the government finally succumbed to the pressure by passing a law allowing concessions to the peasants in 1917. In the following year, Gandhi resumed leadership to fight for the cause of plague and famine affected peasants of Kheda district in Gujarat. Some concessions were also granted to these cultivators by the government. The weapon of satyagraha, was employed by Gandhi, yet another time in an industrial dispute between the workers and owners of a cotton mill in Ahmadabad. The consequence was a wage hike for the workers. Gandhi's leadership infused coherence in the isolated mass movements, which so far was the characteristic feature of the Indian freedom movement.

Till this phase, Gandhi was a co-operator of the British government, helping them variously. However, his faith in the colonial government received a major jolt after the occurrence of two particular incidents. These were the passing of the Rowlatt Act and the following Jallianwallah Bagh massacre and the Khilafat issue. Against the background of the passage of the Rowlatt Act, Gandhi used satyagraha for the very first time assumed a national character. A country wide campaign was launched by Gandhi on 6th April, 1919. Soon Gandhi was arrested. 13th April, 1919, is one of the goriest days in the history of Indian Independence movement. At a public meeting held in Jallianwallah Bagh in Amritsar, several people were brutally shot dead by General Dyer. Although the Congress demanded redressel of grievances, the government acted coldly. In the Khilafat issue too, the British government failed to keep their promise. These incidents triggered an anti British feeling in Gandhi and he emerged as a non co-operator. In the following years, the Indian National Movement celebrated the emergence of Gandhi as a national leader, steering the anti-British movements. In the ensuing NonCooperation Movement, Civil Disobedience Movement and Quit India Movement, Gandhi played a critical role, directing the major motions of the movements.

\section{CONCLUSION}

Gandhi reigns in the hearts of millions of Indians as The Father of the Nation, for the path breaking role that he played not in the Indian struggle for independence but for moulding the national character and the lives of the Indians alike. At a time when the fabric of the Indian society was tearing apart, he accomplished the Herculean task of unifying the nation. Confronted with diverse political ideologies like hard line extremism, the moderate approach and the newly emerging communist forces the confused Indians found solace in the simple philosophies of Gandhi. He worked assiduously for the upliftment of the downtrodden like the dalits and gave them a new identity. Women, under his aegis, found back their long lost confidence and actively participated in the tasks of national cause. Gandhi with similar perseverance championed the cause of the secularism. Thus, the emergence of Gandhi, as a national leader, as a humanist, as a visionary, as a social and political reformer and most importantly as a spiritual leader has been critically instrumental in shaping a new India, firmly rooted in its historical past and at the same time welcoming the progressive trends of modernity.

\section{References}

1. M.K. Gandhi, An Autobiography or the Story of My Experiments with Truth, Navajivan publishing House, Ahmedabad.

2. Mahatma Life of Mohandas Karamchand Gandhi Vol 1, by D.G.Tendulkar ,The Publications division, Ministry of Information and Broadcasting, Govt. of India 
3. K.M. Shrivastava, News Reporting and Editing, Sterling Publishers Private Limited, New Delhi.

4. M. Chalapathi Rao, 'The Press in India', Allied Publishers Private Limited, Bombay, 1968

5. Young India, 18 June 1925

6. Young India, 4 April 1929

7. Ed,Mushirul Hasan,Towards Freedom,Documents on the Movement for Independence in India,1939,Part 2,Oxford University Press,2008.

8. Maulana Abul Kalam Azad,India Wins Freedom,the complete version,Orient Blackswan,2011.

9. David Hardiman, Gandhi in his time and ours, Permanent Black, New Delhi,2009.

10. Ed, K.N Panikkar,Towards Freedom,Documents on the Movement for Independence in India, 1940,Part 2,Oxford University Press,2010.

11. Eds,Ranga Rao and SriranjaniSubba rao,Gandhian Studies Centre, Andhra University and Abhijeet Publications,New Delhi,2011.

12. Pannalal Dasgupta, Revolutionary Gandhi,Earthcare Books,Kolkata,2011.

13. Prem Ananad Mishra, Hind Swaraj,Abhijeet Publications,New Delhi,2012.

14. Ed, Sumit Sarkar,Towards Freedom,Documents on the Movement for Independence in India,1946,Part 2,Oxford University Press,2009.

15. Ed, Bimal Prasad,Towards Freedom,Documents on the Movement for Independence in India,1945,Oxford University Press,2008. 